\title{
電気化学計測における溶液内電位差の効果
}

\author{
增田正孝*，李＼cjkstart恩周*，花田賢志*，有田＼cjkstart誠* \\ * 九州大学 大学院工学研究院
}

\section{The Effect of Potential Difference in the Solution of Electrochemical Measurement}

\author{
Masataka Masuda*, Lee Eun Ju*, Kenshi Hanada* and Makoto Arita* \\ * Graduate School of Kyushu University
}

\begin{abstract}
The effect of potential difference in the solution on the electrochemical system was evaluated with the FEM (Finite Element Method) calculation. We made the theoretical analysis for the effect of Luggin capillary on the potential distribution, and the current distribution on the sample electrode. This calculation evaluated the error in the measurement of electrode potential of the electrochemical system. We proposed the optimal position of Luggin capillary for the electrode potential measurements and mentioned the deviation of the current distribution in the electrode surface by the electrode shapes and by the distance between the electrodes.
\end{abstract}

Key words : FEM, potential difference, polarization measurement, measurement error

\section{1. 緒言}

電気化学測定では, 電極電位を参照電極との電位差で 定義し, 測定に当たっては, ルギンキャピラリィを溶液 に入れ，塩橋を介して参照電極に液絡させる．このとき のルギンキャピラリイの先端位置については, 種々の理 論的解析がなされ, 細管の直径の 2 倍未満の距離には近 づけないようにと多くの教科書にある1)-13).これに従い, およそ数ミリ程度のところに設置するのが一般的であ る. 最近の電子機器の発達のお陰で, 溶液電位差を自動 的にキャンセルしてくれる測定機器もあり，あまり気に する必要がないと思われているが, 改めて, このルギン キャピラリイの位置や電極形状, 電極配置が電気化学測 定に及ぼす影響について考察してみた。電位降下だけで あれば，溶液伝導率と電流密度である程度の予想は可能 である。しかし，シールド効果や電位分布による影響は 簡単には見積もることができない.また，理論計算は， 無限平板電極や球形電極を対象としており，現実の系で の評価は困難である。そこで，数值計算による予測が必 要となる．電位分布を計算し，電極電位の計測値の誤差 を評価することにより，今までの理論的考察の正しさを 確認すると共に, 今の設定法が正しいという裏付けを得 て「心の安寧」を得られればと思うのは著者らだけでは ないと思う。我々は最近, 溶液系の電位電流分布を高精 度で簡便に計算する手法を開発したので，その結果の一 例として報告する.

\section{2. 実}

\section{験}

\section{1 電気化学測定}

溶液は $0.01 \mathrm{M} \mathrm{HCl}+0.5 \mathrm{M} \mathrm{NaCl}$ 水溶液で, 直径 10 $\mathrm{mm}$ の純鉄円形ディスクを作用極に, 対極に厚さ $0.1 \mathrm{~mm}$, $10 \times 10 \mathrm{~mm}^{2}$ の $\mathrm{Pt}$ 板を用いた。試料は直径 $25.4 \mathrm{~mm}$ 厚さ

\footnotetext{
* \% 812-8581 福岡市東区箱崎 6-10-1 (6-10-1, Hakozaki, Higashi-ku, Fukuoka, 812-8581 Japan)
}

$10 \mathrm{~mm}$ の絶縁樹脂に埋め込まれて保持されている. 参照 極は, 飽和 $\mathrm{KCl}-\mathrm{Ag} / \mathrm{AgCl}$ 電極で, ルギンキャピラリイ にはガラス製の外径 $1 \mathrm{~mm}$ のものを用いた. 測定電流密 度範囲は, $-25 \sim+25\left[\mathrm{~A} / \mathrm{m}^{2}\right]$ とした. 電極電位の計測 值に誤差が含まれることを予想しての測定であるので, ガルバノスタティックモードで計測した（TOHOGIKEN 2000). ルギンキャピラリイの作用電極の表面からの距 離を $1 \mathrm{~mm}$ から $15 \mathrm{~mm}$ まで $1 \mathrm{~mm}$ ステップで変化させて 電極電位の変化を測定した. 測定セルは内径 $85 \mathrm{~mm}$ の 円筒形で液面高さは $90 \mathrm{~mm}$ であり $(511 \mathrm{ml})$, 試料極と 対極は間隔 $40 \mathrm{~mm}$ で電極面を対向して配置し, 両極と もセル底部から中心高さで $50 \mathrm{~mm}$ の位置とした。

\section{2 シミュレーション}

FEM による溶液内の電位電流分布計算を行い, ルギ ンキャピラリイの位置を変えたときの IR ドロップの大 きさ, 作用電極表面の電位分布, 電流分布を評価した. 電解液中の電位分布は次の Laplace の式を満足する.

$$
\nabla(\sigma \nabla u)=0
$$

ここで, $\sigma$ は電解液の導電率, $u$ は溶液電位である. これは非圧縮性連続流体に成立する式であり, 電解液中 の電位電流分布を求めるのに妥当であるといえる.また, 伝導率 $\sigma$ の局所的変化にも対応しているため, イオンの 拡散や泳動現象も記述することが可能である.この計算 には溶液内部電位を用いるため, 実測の值を変換する必 要がある。

電極反応の駆動力は電子の金属内部のポテンシャルと 溶液内部のポテンシャル差に帰結される. ただし，その 絶対值を求めることは原理的に実測不能であるので, 電 極反応により変化しない参照電極との電位差でこのポテ ンシャル差を推測する.すなわち, 対象とする電極系の 電気化学反応により変化しないとみなせる電極システム を持つ参照電極の金属電位 $\psi^{R}$ と, 対象となる金属電極 の電位 $\psi^{M}$ の差を以って電極電位 $E$ と定義し, 溶液と電 極との界面ポテンシャル差を推測する。すなわち；

電極電位 $E=\psi^{M}-\psi^{R}$ 
と;

$$
E=\psi^{M}-\psi^{S}+\psi^{S}-\psi^{R}
$$

ここで, $\left(\psi^{S}-\psi^{R}\right)$ は作用電極の電極反応によって変化 しないように設定可能であるため, 未知ではあるが一定 値とみなすことができる。これを $\Delta \psi$ とすると, 溶液電 位は，式 (2)-2を変形して以下のように表される;

$$
\psi^{S}=-E+\psi^{M}+\Delta \psi
$$

ここで， $\Delta \psi$ を電位から減じたものを新たに溶液電位と 定義し直し，さらに作用電極の金属内部電位 $\psi_{\mathrm{w}}{ }^{M}$ を基準 にすると，新たな溶液電位 $u$ を以下のように定義できる；

$$
u \equiv \psi^{S}-\psi_{\mathrm{w}}{ }^{M}-\Delta \psi=-E+\psi^{M}-\psi_{\mathrm{w}}{ }^{M}
$$

この新しい定義の溶液電位を用いると, 作用極, 対極表 面の溶液電位は以下のように表される;

$$
\begin{array}{ll}
\text { 作用極： } & u_{\mathrm{w}}=-E_{\mathrm{w}} \\
\text { 対極： } & u_{\mathrm{c}}=-E_{\mathrm{c}}+\psi_{\mathrm{c}}{ }^{M}-\psi_{\mathrm{w}}{ }^{M}
\end{array}
$$

ここで, $\left(\psi_{\mathrm{w}}{ }^{M}-\psi_{\mathrm{c}}{ }^{M}\right)$ は作用極-対極間のセル電圧 $V_{\text {cell }}$ に 相当するため；

$$
\text { 対 極： } u_{\mathrm{c}}=-E_{\mathrm{c}}-V_{\text {cell }}
$$

と表される.

電極電位 $E_{\mathrm{w}}, E_{\mathrm{c}}$ は計測值であり, $V_{\mathrm{cell}}$ も測定可能であ る. 従って, これらにより電極表面の溶液電位 $u$ を設定 可能となる. 逆に数值計算により求められた電位の值 $u$ から式(6)，(8)を用いて電極電位に換算することが可能 である.

絶縁壁においては, 壁を通しての電流の流入, 流出が 起こらないことから；

$$
\boldsymbol{n} \cdot(\sigma \nabla u)=0
$$

が成り立つ.ここで, $\boldsymbol{n}$ は壁への垂直べクトルである.

このように境界条件を設定し（1）の偏微分方程式を解

くことにより溶液電位分布を求めることができる.

さらに，電流密度 $j$ は Ohm の法則の微分型；

$$
j=-\sigma \nabla u
$$

より, 電位勾配から求めることができるため, 電解液中 の電位-電流分布を決定することができる.

計算には幾何学的条件と, 電気化学的条件を境界条件 として設定する必要があるが, 今回は, 溶液導電率 $\sigma=$ $5.09[\mathrm{~S} / \mathrm{m}]$ とし ${ }^{5)}$, 分極は電気化学測定で計測した電位一 電流密度の関係から線形近似して設定した。また，計算 を簡単にするため, ルギンキャピラリイは直径 $1 \mathrm{~mm}$, 長さ $10 \mathrm{~mm}$ の円柱状絶縁体として評価した。この円柱 絶縁体の先端部の溶液電位 $u_{\mathrm{L}}$ を用いると，このルギンキ ヤピラリイで計測される作用電極の電極電位の值 $E_{\mathrm{L}}$ は (6) 式より;

$$
E_{\mathrm{L}}=-u_{\mathrm{L}}
$$

を得る。この電極電位がルギンキャピラリイの位置によ りどのように変化するかを評価した．また，試料表面上 での電極電位分布も計算し，キャピラリイが与える電流 分布への影響も考察した.

\section{3. 結果および考察}

Fig. 1 に分極曲線を示す.この結果は，ルギンキャピ ラリィを試料表面から $2 \mathrm{~mm}$ の位置に設定して測定した ものである.

これから, 試料極をカソード分極したときの電流密度 $10.0\left[\mathrm{~A} / \mathrm{m}^{2}\right]$ 近傍での分極条件として, 電極電位 $E_{\mathrm{w}}$

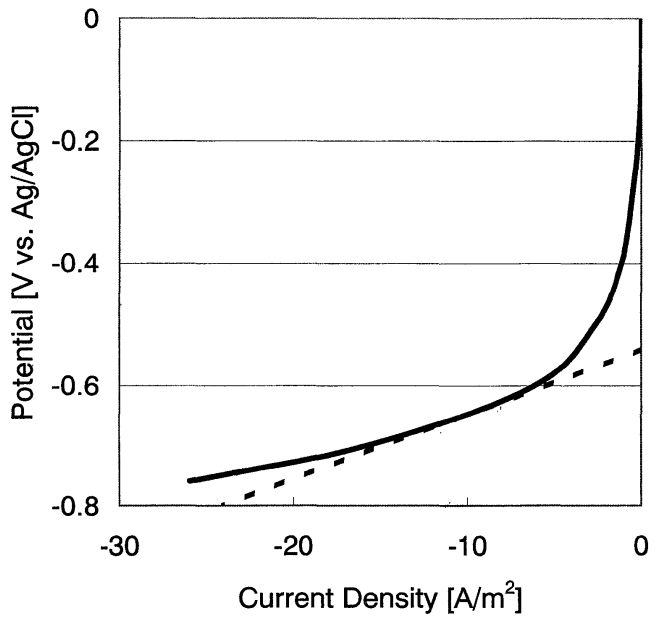

Fig. 1 Cathodic polarization curve of $\mathrm{Fe}$ in the $0.01 \mathrm{M} \mathrm{HCl}+0.5 \mathrm{M}$ $\mathrm{NaCl}$ solution.

[V vs. $\mathrm{Ag} / \mathrm{AgCl}]$ と電流密度 $i\left[\mathrm{~A} / \mathrm{m}^{2}\right]$ を次式で近似した；

$$
E_{\mathrm{w}}=-0.5361-0.01108 i
$$

同様に，対極の分極特性も測定し，Pt 対極のアノード分 極の電極電位 $E_{\mathrm{c}}[\mathrm{V}$ vs. $\mathrm{Ag} / \mathrm{AgCl}]$ と電流密度 $i\left[\mathrm{~A} / \mathrm{m}^{2}\right] に$ 対しては,

$$
E_{\mathrm{c}}=-0.4192+0.01703 i
$$

で近似した。

Fig. 2 にキャピラリイの位置と電極電位との関係を示 す。白丸が計測值である。このとき，電流密度 10.0 $\left[\mathrm{A} / \mathrm{m}^{2}\right]$ のカソード電流を通電している。 この結果から, キャピラリィと試料の距離が離れるほど, 測定電極電位 が低下することが確認できる。しかし，溶液中での IR ドロップを低隇するために，キャピラリィを試料に近接 し過ぎた場合, キャピラリイにより試料の一部が電気的 にシールドされ，電極反応を疎外することが予想される ため，最適位置を的確に定めることは困難である。そこ でシミュレーション計算が必要となる.

シミュレーション結果の一例として溶液内部の電位分 布を Fig. 3 に示す. 試料と対極の表面電位分布と, 電極 中心とキャピラリイを通る面での断面の電位分布を示し ている，この值は，(6)，(8)式からわかるように，試料

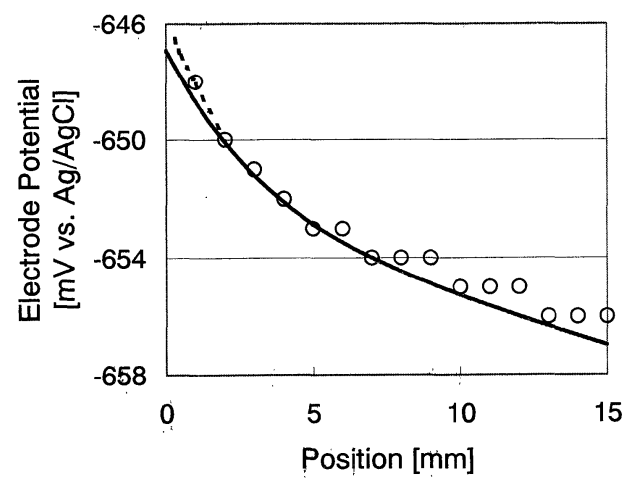

Fig. 2 Relationship between the electrode potential and the distance of capillary and electrode.

open circle : measured value, solid line : calculated value without the effect of capillary, broken line : calculated value with the effect of capillary. 


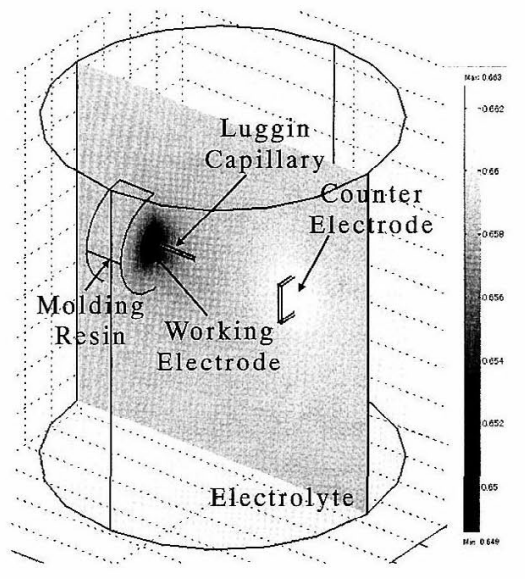

Fig. 3 Potential distribution in the electrolyte of the cell.

電極表面では, 電極電位の值の符号を逆にしたものに相 当し，対極表面では，セル電圧と電極電位の合計の值の 符号を逆にしたものに相当する. 対極をアノードとして いるため，対極から試料電極に電流が流れ込み，対極か ら試料に向かって溶液電位が低下しているのがわかる。 これは, キャピラリイの位置により, 測定される電極電 位の值が変化することを意味している．距離が増加する ほど, キャピラリイ先端の溶液電位は上昇し, 測定され る電極電位は距離の増加と共に減少することが確認でき る.Fig. 2 には, 計算により求めたキャピラリィ距離と 電極電位の関係を実線で示している。この実線は, キャ ピラリイが十分に小さく，溶液電位分布に影響を与えな い場合を示しており，キャピラリイによる影響を考慮し た場合を破線で示している。これによると，距離が 2 $\mathrm{mm}$ 未満になると, キャピラリイの影響が顕著となり, 計測される電極電位が上昇することがわかる. 理想的に は, キャピラリイが存在しない場合の, 距離 $0 \mathrm{~mm}$ での 值一 $646.9 \mathrm{mV}$ が求めるべき正確な電極電位であるが，こ の值にはならないことがわかる.これらのことから, 溶 液中の IR ドロップを極力小さくすると共に, 試料電極 表面での電極反応を乱さない距離として，この例では 2 $\mathrm{mm}$ が得られる.この場合, 溶液中での試料表面からキ ヤピラリイ先端までの IR ドロップは約 $3 \mathrm{mV}$ になる.

キャピラリイによる電極表面での電流分布の影響を Fig. 4 に示す. 試料中心部を位置 $0 \mathrm{~mm}$ とし, 縦軸に電 流密度を表示している. キャピラリィの影響が無い場合 でも幾何学的形状による影響のため, 試料の周縁部に電 流が集中していることがわかる。試料全面で $10.0\left[\mathrm{~A} / \mathrm{m}^{2}\right]$ の平均電流密度となるように設定しているが, 中心部で は $9.87\left[\mathrm{~A} / \mathrm{m}^{2}\right]$, 周縁部では $10.18\left[\mathrm{~A} / \mathrm{m}^{2}\right]$ の電流密度分 布を示している。これに対し，キャピラリイが試料に近 づくと, キャピラリイによるシールド効果のため, 電流 が中央部で減少している，この影響は距離が小さくなる ほど顕著となっており，しかもキャピラリイ外径 1.0 $\mathrm{mm}$ より大きくなっている.このキャピラリィによるシ ールド効果が $2 \mathrm{~mm}$ 未満の距離で顕著となることが確認 できた，別の計算により，キャピラリイの直径を変化さ せた場合でも, その 2 倍程度の距離未満となるとシール ド効果による電流分布への影響が顕著となった。これか ら, キャピラリィ直径の 2 倍程度まで影響が及ぶこと,

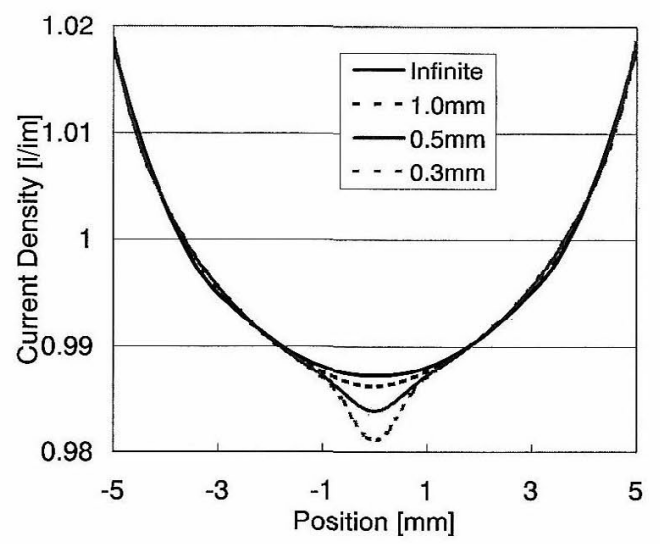

Fig. 4 Current distribution of the round electrode with distance between capillary and electrode.

また, 計測のための最適位置は試料からキャピラリイ直 径の 2 倍程度であることが確認できた.

次に $10 \times 10\left[\mathrm{~mm}^{2}\right]$ の正方形電極の場合における，電 極形状による電流分布への影響を計算した．この電極が 直径 $24.5 \mathrm{~mm}$ の絶縁樹脂に埋め込まれているとしたとき の, 試料表面の対角線に沿った電流分布を Fig. 5 に示す. 平均電流密度は $10.0\left[\mathrm{~A} / \mathrm{m}^{2}\right]$ とした。これから，コーナ 一部での電流集中が $3 \%$ 程度であることがわかる. 分極 抵抗が減少した場合はこの電流分布の不均一は大きくな り，分極抵抗が $1 / 10$ になると， $30 \%$ を超える不均一を 生ずることが示された.これは, 電極電位の值では, そ れぞれ $4.4 \mathrm{mV}$ と $6.7 \mathrm{mV}$ の不均一に相当する.これらの 電極電位の值は, 電流值により変化するため, 大きい電 流を通電する場合には，より誤差が大きくなることは当 然予想される。

このように, 電極の形状, 電気化学特性によっては計 測される電極電位の䛊差が大きくなる場合あることを認 識すべきである。

次に, 対極との距離を評価した. モデルとして, 直径 $24.5 \mathrm{~mm}$ の円筒形電解槽において, 対極を直径 $10 \mathrm{~mm} の$ 円板とした場合の試料極表面の電流分布を求めた。試料 極は直径 $24.5 \mathrm{~mm}$ の円板とし, 電極間距離を $5 \mathrm{~mm} \sim 20$ $\mathrm{mm}$ に変化させた場合の試料極表面の電流分布を Fig. 6 に示す，横軸の值は電極の直径に沿っての位置を示す。 縦軸は, 平均電流密度で標準化した值で電流值を示して

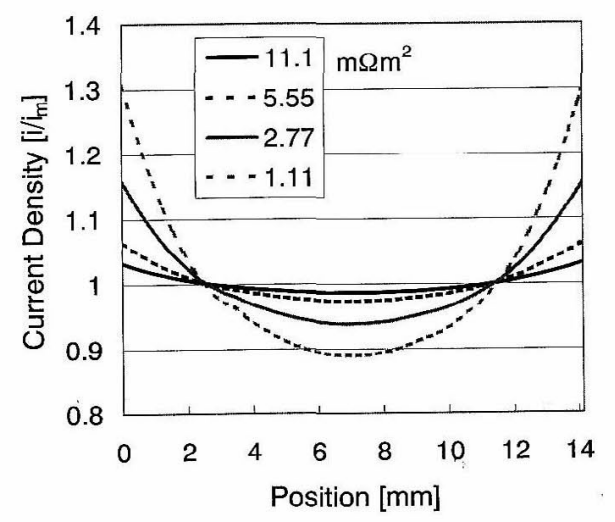

Fig. 5 Current distribution of square electrode with polarization resistance. 


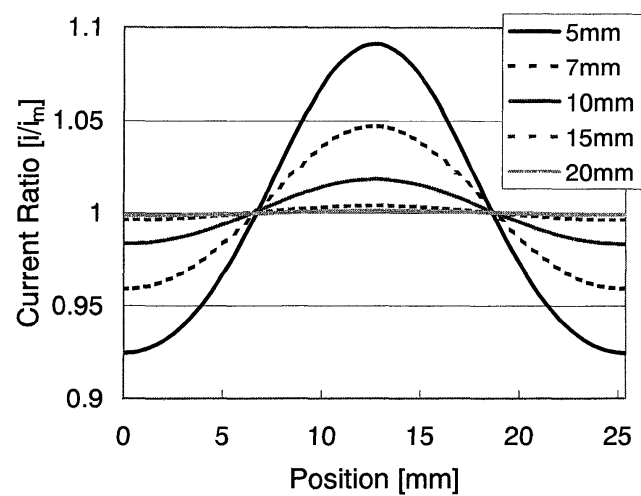

Fig. 6 Current distribution of round electrode with the distance between working electrode and counter electrode.

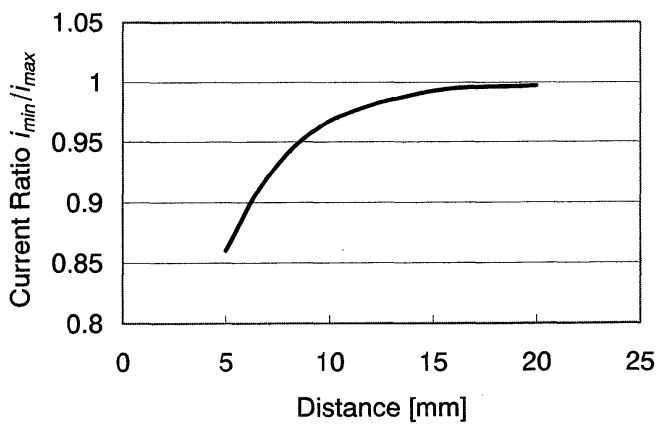

Fig. 7 Current ratio with the distance between working electrode and counter electrode.

いる. Fig. 7 には, 試料極表面での電流密度の最小值と 最大值の比の值を電極間距離の関数として表示してい る.これから, 対極との距離を $20 \mathrm{~mm}$ 以上に離せば対 極の形状による影響は $1.0 \%$ 未満となることがわかる. 一般に円板状対極の場合, その直径の 2 倍以上の距離で 対極の形状による試料極表面の電流分布への影響は無視 しうると計算された。

このように，溶液内 IR ドロップによる電位計測誤差 だけでなく, 試料表面での電流分布の不均一性による電 極電位の偏差が存在するため, 計測される電極電位の值 の評価には注意を要する.より正確な計測には, 電極の 形状やセル形状も含めた検討が必要であることが計算に より示唆された.

なお，今回の計算では電気化学的境界条件として，測 定した分極曲線を用いているが，これには溶液内 IR ド ロップによる計測誤差が含まれることが示されたため, 自家撞着しないように，キャピラリイを試料から $2 \mathrm{~mm}$ の距離に設置した場合の計測值となるように境界条件を 設定している.
電極反応は, 電極種, イオン種, イオン濃度, 温度, 電位，電流などで大きく変化するため，ここで示した計 算結果をすべての系に適用することはできないが，電極 電位計測における計測誤差の傾向をある程度表している といえる。

\section{4. 結論}

簡単な実験とシミュレーションにより，ルギンキャピ ラリィと試料形状，電極配置が与える電位電流分布への 影響について考察した．結果として，キャピラリイ先端 径の 2 倍程度の距離を試料から離すのが電極反応を乱さ ず，IR ドロップも小さくて電位計測には最適であること が再確認された，対極との距離は，円板形状の場合，対 極直径の 2 倍以上離す必要があることが示唆された．試 料を絶縁埋め込み樹脂で保持する場合は，周縁部への電 流集中により電極電位に偏差が生ずることが示された.

シミュレーションは煩雑さを伴わずに簡単に境界条件 を変更できるため，その精度を十分に認識しながら用い れば非常に役立つことがわかる。 な打今回の計算では, キャピラリイ表面での毛管現象, 膜電位や流動電位など の現象は考慮していない。あくまで，溶液電位-電流分 布の影響だけを評価したものであることを付け加える.

今回の結果から，読者の測定法が適正であったことを 祈る。また，計測誤差がどの程度であるのか一度考察し て見られるのも，電気化学現象を理解する上で重要であ ると思う．電気化学に関わる研究の一助になれば幸いで ある。

\section{参 考 文 献}

1) A.Fujishima, M.Aizawa \& T.Inoue, "Electrochemical Measurement Methode", Gihodo (1984).

2) S.Haruyama, "Electrochemistry for Surface Scientist", Corona Shuppan (2001).

3) Denkikagakukai, "Electrochemical Measurement Manual", Maruzen (2002).

4) Denkikagakukyoukai, "Electrochemical Measurements" (1972).

5) Nihon Kagakukai, "Tables of Chemistry", Maruzen (1995)

6) M.Takahashi \& N.Masuko, "Kogyodenkai no Kagaku”, AGNE (1979).

7) S.Yoshizawa, "Denki Kagaku", Kyoritsu Zensho.

8) T.Oki, "Kinzoku Denkikagaku”, Kyoritsu Shuppan (1994).

9) J.Newman \& M.Takahashi, "Electrochemical Systems", Corona (1976)

10) N.Sato, "Electrochemistry", Nittetsu Gijutsu Center.

11) T.Osaka, N.Koyama and T.Osaka, "Electrochemical Method", Kodansha Scientific (1989).

12) S.Tojima and H.Sasaki, "Electrochemistry", Ohm-sha (1976).

13) S.Barnartt, "Encyclopedia of Electrochemistry", J. Wiley \& Sons, p.428 (1964).

(Manuscript received October 8, 2003; in final form February 18, 2004)

\section{要 旨}

電気化学計測における溶液内電位差の効果についてFEM計算を元に考察を行った．通常の計測で用いら れるルギンキャピラリイによる電位分布の変化, 電極形状による電極表面上での電位電流分布の影響など について数值解析による理論的考察を行い, 電気化学計測に含まれるこれら溶液内電位差による誤差を評 価した。ルギンキャピラリィの最適位置を提案し, 電極形状, 電極間距離による電極表面での電流分布の 不均一性について言及した。

キーワードＦEM (有限要素法)，溶液内電位差，分極測定，計測誤差（測定誤差） 